\title{
Urban legends in Poland
}

\author{
Marta Wójcicka
}

\begin{abstract}
The aim of this article is to determine the genre pattern of texts categorised as urban legends. We will analyse the genre from a synchronic perspective, using Maria Wojtak's (2004) description of genre criteria: its structural aspects (structure model, more specifically the issue of text frame), pragmatic aspects (images of the speaker/hearer, their aims in communication), cognitive aspects (the range of topics and how they are presented with reference to the notions of perspective, point of view, values, linguistic worldview), as well as stylistic aspects. The main aim of the article is to provide a definition of the genre of urban legends. In our view, it might be achieved through comparing and contrasting the genre with a closely related traditional folk genre, that of religious folk tales.
\end{abstract}

Keywords: urban legends, structural aspects, pragmatic aspects, cognitive aspects, stylistic aspects, folk tales

Contemporary legend is a genre of present day folklore described in folklore studies as a thriller story (Simonides \& Hajduk-Nijakowska 1989), urban legend (Brunvand 1981, 1986, 2002; Barber 2007; Czubala 1993; Donovan 2004), contemporary myth, gossip, rumour (Hajduk-Nijakowska 2005), sensation, hearsay, and urban tale (Rydzewska 2004).

An analysis of the various names of the genre suggests that its most relevant characteristics include a subject for the story which is out of the ordinary and frequently located in urban space. The story takes place at present time and involves characters who behave in a way that is difficult to believe, furthermore, the storyteller expresses an attitude towards the subject.

However, it is the theme, not the genetic features of the genre, that dominates the current studies of the subject. Dorota Simonides and Janina HajdukNijakowska (1989) define urban legends as "tales based on singular, unusual, extraordinary and bizarre situations. The stories strongly affect public imagination [...] An international character is a peculiar feature of these sensational 
and often tragic or even macabre tales" (Simonides \& Hajduk-Nijakowska 1989: 407). Dionizjusz Czubala defines the urban legend as "a short, single-topic piece of prose about some unusual events of contemporary life, which spreads easily and reaches a very wide audience" (Czubala 1985: 83).

More recent research has pointed at other defining aspects of the urban legend - namely its purpose and function. Czubala tries to specify the purpose of urban legend in the following words:

It voices the lack of trust towards the dominant groups, as well as a need to have say about one's fate. It is also an expression of opposition against vagueness of situations, lack of information, and manipulation. It is a means as well as the result of political conflicts and economic competition. It sometimes becomes a weapon, used instead of physical violence. It explains unusual and supernatural events in a natural world (Czubala, 1993: 134).

Although, according to Joanna Rydzewska, contemporary sensational story set in an urban setting is characteristic of an urban legend (Rydzewska 2004: 118), its only constant feature is its function. The link between urban legend and social fears has been noticed before. "The forces behind rumours are mainly anxiety, fear and a sense of danger," claims Hajduk-Nijakowska (2005: 146). That is why Klaus Thiele-Dohrmann (1980) metaphorically calls rumours "a vent for human fears and aggression". Urban legend also "helps to ease tension and to regain the sense of predictability of the world around us" (HajdukNijakowska 2005: 145). Jan Brunvand has pointed at three defining aspects of the urban legend, stating that "they contain three essential elements: a strong basic story-appeal, a foundation in actual belief, and a meaningful message or "moral"' (Brunvand 1981: 10).

According to Rydzewska (2004: 118), urban legends do not only give answers to contemporary civilization problems, they also provide entertainment. She also stresses the educational function of urban legends - "these legends, unreal, but at the same time inspired by true events, serve as an important source of education" (Rydzewska 2004: 120). Moreover, they are "an excellent indicator of public feelings" (ibid.). Urban legends constitute a commentary to the contemporary social situation.

Hajduk-Nijakowska focuses on different functions of urban legends. In her book "Żywioł i kultura" ("Element and culture") she stresses the fact that the character of the genre "is mainly determined by specific, folklore-generating situations, and that is the function of this type of tales in social circulation" (Hajduk-Nijakowska 2005: 148). "A rumour is also a projection of emotions, as 
well as of the natural need to find the ones responsible for a tragedy" (HajdukNijakowska 2005: 153).

Czubala's axiological concept was supposed to become a significant breakthrough in urban legend studies. However, it only constituted a return to the thematic criterion, which has been the basis for categorising different subtopics of urban legends: political, medical, erotic, economic, religious, parapsychological, or macabre stories, as well as those about robberies, monsters, aliens, oddities and anomalies (Czubala 1993: 138).

The relationship between urban legends and media has become the most recent object of folklore studies. Hajduk-Nijakowska claims that

[...] a function of a contemporary rumour is largely defined by the context of mass media. This link with the media is currently the most important feature of a rumour, as the media do not only reinforce its public circulation while stimulating interest in the information about the event, but often creates it altogether. It is a completely new situation, when two circulations - the mass media and folkloristic circulation - merge (HajdukNijakowska 2005: 148).

The relationships and mutual influences of mass and folk culture are not the subject of this article. Instead, its aim is to present the text of an urban legend as a structure, that is to outline a genre-specific pattern on the basis of texts described by the term, doing it from a synchronous perspective, as well as to demonstrate the structure of the presented world (characters, time, space). We will use Maria Woitak's criteria for describing texts belonging to one genre. Wojtak (2004: 16) mentions the following components of a genre as a whole:

- structural aspect of the defined composition model: text frame, division into segments and the relations between them, that is "the various horizontal arrangements that are typical for the genre, as well as the text's architecture" (ibid.);

- the pragmatic aspect of the communicative situation: the sender and the addressee, the aim of communication;

- the cognitive aspect: the subject and the way it is presented (perspective, point of view, hierarchy of values, components of the depictured world);

- the stylistic aspect: pragmatically defined indicators of style determined by structure (ibid.: 16-17). 


\section{The structural aspect of urban legends}

The most important structural characteristic of urban legends are the elements of a text frame: the initial and final formulas. Both are dominated by testimonial formulas, which indicate the attitude of the teller towards the story. In an urban legend, the most common demarcation of testimoniality is a single verb of perception ('to hear').

Styszatam, że szedt pijany i zasnąt w kacie podwórka przy śmietniku. I've heard that he walked drunk and fell asleep in the corner of the yard, next to the waste bin. (Czub Mit: 81)

In some cases, the verb 'to hear' is complemented by information about the place and time the narrator heard the story:

Tośmy styszeli nie tak dawno, bo to sie zdarzyto w Pińczowie.

We heard this not so long ago, because it happened in Pińczów. (Czub Mit: 113)

Ja to styszałam bodajże już cztery lata temu, że w którejś z roślin, bodajj̇e papirusie czy którymś, zaczęty wychodzić tarantule.

I heard about it, I think it was four years ago, that in some plants, papyrus probably or something like that, tarantulas started to come out. (Czub Mit: 86)

Ja o tym styszatam dwa miesiące temu, będąc $w$ sanatorium, że jakiś mężczyzna miat tendencję dobierania się do kobiet.

I heard about it two months ago, when I was in a sanatorium, that a man had a tendency to molest women. (Czub Mit: 44)

The time between a person hearing the story and retelling it is not long (not long ago, two months ago), which makes the tales fresh and popular.

The places where the teller was introduced to the story are usually indeterminate (a train, village, sanatorium) and characteristically frequented by a number of people. This facilitates the propagation of the incredible stories, and their fast circulation makes their verification impossible. Thus, in some texts, the narrators themselves describe the stories as rumours:

To sa plotki z ulicy, wręcz z autobusu i to dość popularne, szczególnie wśród ludzi spotykających się $w$ kolejkach $i$ autobusach. Mówi się, że to się dzieje na Starym Mieście. 
These are the rumours circulating on the streets, in buses even, and quite popular, especially among people who meet in queues or on buses. People say that they happen in the Old Town. (Czub Mit: 66)

Usually, the verb of perception in an urban legend does not reveal the source of the story. This fact indicates its low credibility, and it distances the teller from the communicated content:

Styszatam o jednym facecie, że wygrat $w$ totolotka. To byto $w$ Gotonogu. I've heard about one guy who won the lottery. It happened in Gołonóg. (Czub Mit: 26)

In urban legends, the sender often cites a contemporary written or media material:

W radio styszałam, że matka kupita dzieciom banany.

I've heard on the radio that a mother bought her children some bananas. (Czub Mit: 87)

Nie wiem, chyba to gdzieś czytałem, Jedzie kierowca $i$ wzią po drodze podróżnego.

I don't know, I guess I've read it somewhere: a driver picks up a hitchhiker on the road. (Czub Mit: 120)

Jeden facet - to pisato "Veto" - zamordowat trzy kobiety i zrobit z nich weki. One guy - "Veto" wrote about it - murdered three women and jarred them. (Czub Mit: 72)

Ja o tym czytatam. Byto ogtoszenie $w$ prasie, $\dot{z}$ e Szwed poszukuje atrakcyjnej Polki.

I've read about it. There was an advertisement in the press that a Swede is looking for an attractive Polish woman. (Czub Mit: 38)

Czytatam to gdzieś, już nie pamiętam, gdzie, że langusta weszła $w$ cztowieka $i$ on zmart.

I've read about it, I don't remember where, that a lobster got inside a man and he died. (Czub Mit: 90)

In most of the texts, the teller is unable to specify the media source of the heard/read story. Sporadically, titles of magazines are mentioned (like "Politics" or "Veto"); titles that, depending on the status of the quoted newspaper, can validate or disprove of the tale. However, even if the title of the source 


\section{Marta Wójcicka}

is mentioned, it is accompanied by an expression of uncertainty - "I think", "probably", "maybe".

Another source which is often cited in urban legends is friends and colleagues:

Kolega mi mówit, że widziat taka scenę. Wszedt pan, usiadt przy stoliku, wyszedt mu biaty szczur na ramię: biaty, pięknie wypasiony i przygladat się ludziom.

A friend told me that he's seen a scene like this. A man came in, sat by a table, and a white rat came out on his shoulder: it was white, very well fed and it observed people. (Czub Mit: 92)

Mnie koleżanka opowiadata, że jeden pan postawit samochód $i$ poszedt na grzyby.

My friend told me that one man left his car and went to pick mushrooms. (Czub Mit: 93)

Opowiadat nam Janusz, nasz kolega z Bielska, że tam podobno jest prawdziwe siedlisko zarażonych.

Janusz, our friend from Bielsko, told us that reportedly there is a real hotbed of infection. (Czub Mit: 67)

These types of sources, although they are specific, are nondescript - the only information that is provided is either the name of the 'source' or their place of residence, which, in consequence, does not authenticate the tale. It often happens in the abovementioned forms that the 'source' is presented as a Chinesebox structure ("My friend told me that his friend had said/seen [...]"). Rarely, the sources themselves witness or participate in an event. The story is often heard on a trip to a different, remote location.

When it comes to the frequency of formulas in the frame of urban legends, the second place belongs to authenticity formulas, including alethic (assertive) as well as epistemic modality, as seen in the examples:

Ja znam prawdziwy taki wypadek. To się zdarzyto miesiąc temu w czasie strajku w FSO w Tychach.

I know about such true accident. It happened a month ago during a strike in the FSO factory in Tychy. (Czub Mit: 49)

Młodzi mieli się pobrać $i$ wszystko było do wesela przygotowane. To było $w$ Sopocie $z$ miesiac temu. Ale to jest prawdziwa historia, moge ci to zagwarantować. 
The young were supposed to get married; everything was prepared for the wedding. It happened in Sopot about a month ago. But it's a true story. I can guarantee it. (Czub Mit: 39)

Also epistemic modality is present in texts:

Działa podobno w Polsce nielegalna firma, która skupuje dziewczynki i wysyta na Zachód.

Allegedly, there is an illegal company in Poland that buys young girls and sells them in the West. (Czub Mit: 37)

Podobno jest taki człowiek, co wszelkie robactwo z człowieka wyciagnie.

Reportedly there is a man who can pull out all the vermin from a person. (Czub Mit: 90)

Byto trzech braci, nie wiem, w jakim mieście, ale to styszałam pare razy. Opowiadali to moi koledzy w Baranowiczach.

There were those three brothers, I don't know in which city, but I've heard it a couple of times. My friends from Baranowicze told me. (Czub Leg: 52)

The stories that are described by the teller as true come with information about the time and place where it happened in order to further legitimise them. Doubt, expressed by words such as 'reportedly' or 'allegedly' and described by Wierzbicka as a precaution towards the story (Wierzbicka 1971), is expressed often when the story features extraordinary characters or places of the events.

\section{The pragmatic aspect of urban legends}

The analysis of the ways the sender talks about the events in urban legends informs us about the pragmatic aspect of the genre. Thus, even in the abovementioned formulas, a double sender can be identified: the external one, who tells the story and builds the text, and the internal one, the original informant or the 'source' of the tale.

The addressee emerging from the text is a person living in the same reality as the sender; he/she is a participant in the well-known events described in the text. The sender often appeals to shared knowledge at the very beginning while initiating the dialogue:

A styszeliście o Jantarce? Podobno żyje.

Have you heard about Jantarka? Reportedly, she's alive. (Czub Mit: 38) 


\section{Marta Wójcicka}

Nie wiem, czy styszeliście, ale przecież się o tym mówito, że jak byty te ktopoty z mięsem, to kradli zwierzęta $z$ ZOO.

I don't know if you've heard, but people said that when there were those meat shortages, somebody stole animals from the zoo. (Czub Mit: 78)

To pewnie już styszateś, o tym facecie, co mordowat ̇̇ony w Dąbrowie Górniczej.

You've probably heard about it, about this guy who murdered his wives in Dąbrowa Górnicza. (Czub Mit: 109)

The stories have a wider social aim. The topics that are used to construct urban legends (sex, murder, suicide, missing people, AIDS infections, illegal kidney transplants, etc.) point at significant problems and dangers that concern the society in general and tellers of the stories in particular. The choice of such topics as the basis for the text demonstrates their main intention: the need to explain and demystify the unknown, the mysterious and dangerous situations (child kidnappings, AIDS infections), and by these drastic descriptions, to get accustomed to them. The main aim is not, therefore, to entertain, but to explain and "tame" the unsettling reality. Other intentions - including entertainment and didacticism (such as a warning against random sexual encounters) - are only derivates of the main task of urban legends (see also Kalmre 2013, this volume, for additional thoughts on the functions of urban legends as means of identity construction).

The re-tellers of urban legends, confused by the multitude of bizarre events and information about them, do not know the reasons behind the dangerous phenomena in the surrounding world. Nevertheless, they do not try to introduce paranormal factors (ghosts, spectres, vampires, etc.) into the stories, as it happened in traditional tales. Instead, they blame the wickedness of people around them (HIV carriers inject the virus into other passengers on a bus, a gang kidnaps a girl or a woman, takes her abroad and sells her to a brothel), in frauds ("A random guy stood by the carpet and pretended to be the owner, sold this carpet, took the money and ran away" (Czub Mit: 20)), dishonesty, lack of morals. In some texts the dangers are a result or a consequence of a joke - e.g. a story of a Polish man in Libya who accidentally sells his wife to an Arab.

Danger originates from other people, but it is also present in other elements of the surrounding world - plants (worms in bananas, poisonous spiders in yuccas), pets (a cat attacks the sleeping owner at night and chokes him), everyday articles that endanger our lives instead of helping us (HIV-infected band aids, Ixi washing powder hidden inside a bed that becomes the source of grandmother's illness). 
The story-teller is a person who seeks for rational causes of phenomena, yet searches for explanations in common knowledge and observations rather than in scientific or paranormal knowledge.

Another significant element of the pragmatic aspect of the discussed texts is their situational character. The stories are always created in situations of danger or misinformation and these situations result in stories. A situation known from personal experience or information heard in the media can be a source for these tales.

\section{The cognitive aspect of urban legends}

The topics of urban legends have been already discussed in this article. Therefore, this analysis will focus on other cognitive elements, namely the characters and space.

The characters and protagonists of urban legends, often referred to by the initial existential formulas, are contemporary people with contemporary problems (hippies, drug addicts: Byt jeden narkoman $i$..., 'There was this one drug addict and ...' (Czub Mit: 66), anonymous people (a guy, one lady): Jeden facet grat kilka lat $w$ totolotka, 'A guy has played the lottery for a couple of years' (Czub Mit: 26)), and people depicted in friendly relations or family relations (husband-wife).

The protagonist of an urban legend is often a person whose embarrassing failings are exposed: Kobieta lubiła mu takie dowcipy robić, tapała go w intymne miejsca, 'A woman liked to trifle with him and grabbed him by his private parts' (Czub Mit: 13).

The space where urban legends take place is, as the name of the genre indicates, cities and towns. Therefore, urban legends present elements of space that in the traditional division between the city and the country clearly belonged to the city and defined it: these are locations such as discos, stores, taxis, buses. The places named in urban legends are large cities (Szczecin, Kraków), places, where large populations of people who do not know each other are living together. Those places emphasise that anonymity, loneliness and danger awaits a person who is lost in the crowd. It is stressed that in the countryside where everyone knows everyone and everything, a person is safe. Moreover, the space depicted in urban legends is often international, with the events taking place during journeys (from Turkey, Russia, Germany, Yugoslavia to Poland, or on the way to holidays in France). Examining the image of the city and different countries presented by the genre would be an interesting aspect of further research in Polish urban legends. 
The second type of space often mentioned in the urban legends is the space normally considered safe, close and tamed - one's home. In urban legends even home is no longer a safe place, as the dangers of the outside world intrude it:

W radio styszałam, że matka kupiła dzieciom banany. Położyta je $w$ tazience i miała je płukać. Wyszła na chwilę, wraca, a w nocniczku dla dziecka tazi skorpion. Wypadt z tego banana prosto do nocnika, jak by nie zauważyta, to by jej zabit dziecko.

I've heard it on the radio that a mother bought some bananas for her children. She put them in the bathroom in order to wash them later. She went outside for a moment and came back, and there was a scorpion in the child's potty. It came out of the banana straight into that potty, if she hadn't seen it in time, it would have killed her child. (Czub Mit: 87)

The protagonist is often the one who defiles home and endangers himself or herself. Even at home they cannot hide themselves from the world:

Chyba dwa albo trzy lata temu zdarzyta się koło nas taka historia. Koto Wolbromia jest miasteczko Charsznica. Byta tam dziewczyna, która miała psa. Odbywata z nim regularne stosunki. I nic by się nie wydato, bo robita to skrycie, ale raz, kiedy to robita, połaczyta się z psem. Pies zaczą szczekać, wyć, bo go bolato, i wpadli do pokoju rodzice. No i co? Szok, konsternacja, ale dziewczynę trzeba ratować. Sami nie potrafili $i$ wezwali lekarza. Lekarz przyszedt i tu - humorystyczna scena. On mówi do rodziców: "Trzymajcie tego zięcia, żeby mnie nie pogryzt." To byta bardzo głośna sprawa $w$ Wolbromiu.

I think it was two or three years ago when this happened in our area. Near Wolbrom there is a small town called Charsznica. There lived a girl who had a dog. She had regular intercourse with it. And nothing would ever be revealed about what she does in secret, but once, when she did it, she and the dog stuck together. The dog started barking, howling, because it hurt, and her parents run into the room. And what happened? Shock, consternation, but the girl had to be helped. They couldn't do it themselves, so they called a doctor. The doctor came and a comical scene unveiled. He said to the parents: "Hold this son-in-law of yours, so he doesn't bite me." It was a very well known accident in Wolbrom. (Czub Mit: 56-57)

The characters and place of action display the hazards of civilization (c.f. the story of the grandmother and her Ixi washing powder), e.g. shortages of some products during the communist period in Poland gave rise to several urban legends. The protagonists of some urban legends are sexual deviants (a father rapes the daughter, a brother and a sister have a baby, a primary school girl 
has a sexual relationship with an adult man, women rape a man, a man or a woman uses a technical device to masturbate, e.g. a spin dryer). The world depicted in urban legends is governed by chance - a man, persuaded by the seller to buy the last lottery ticket, wins a million; some lucky person finds dollars in a parcel from abroad. The characters are sometimes presented from the perspective of their occupation: a priest, a dentist, a hairdresser. In these texts, the occupation is always deprecated and shown in a context that lowers its social status - a priest stuck together with his lover during sex, an HIVpositive dentist or barber infecting his patients:

Fryzjer hotelowy to byt, panie, ktoś! Dziś co? Nikt do niego nie pójdzie się golić. Panie! Boja się AIDS! [...] Ja sam bym nie poszedt.

A hotel barber used to be an important person! And now? No one comes to get shaved. They are all afraid of AIDS! [...] I wouldn't go myself. (Czub Mit: 61)

The world in an urban legend is presented from a point of view of an average person - a person who is weak and lost in the evils of contemporary civilization.

\section{The stylistic aspect of urban legends}

Urban legends are short, single-threaded texts that are stylistically rather economical. Their structure can be divided into two segments: the first part is the depiction of a situation that has a surprising, amusing or tragic ending (short, single or compound clauses are used), whereas the second part is the explanation of the causes of such an ending (with compound clauses), e.g.:

Na weselu w Jaworzynie zdarzyta się dziwna historia. Miało być wesele. Pani mtoda wypożyczyta sobie ślubna suknię w wypożyczalni. Ślub się odbyt $i$ wesele trwato $w$ najlepsze. Nagle pani mtoda zastabła $i$ zmarta.

A strange thing happened during a wedding reception in Jaworzno. There was supposed to be a wedding. The bride borrowed a wedding dress from a bridal shop. There was a wedding and a wedding reception, but in the middle of the party, the bride collapsed and died.

Zaczęto się śledztwo $i$ co się okazało? Suknię do wypożyczalni sprzedali grabarze. Ściagnęli ją z kościotrupa, wyczyścili $i$ sprzedali, a w niej byt jad trupi. Pani młoda zacięta się zamkiem, jak ją wktadała, i zmarła. To byta święta prawda, bo ja to znam od koleżanki, a koleżance opowiadała jej matka, która zna to od oficera MO, który prowadzi w tej sprawie śledztwo. Ma się odbyć podobno sąd nad tymi grabarzami. 


\section{Marta Wójcicka}

An investigation followed, and what turned out? The dress was sold to the bridal shop by gravediggers. They took it off a skeleton, cleaned it and sold it, and there was cadaveric poison in it. The bride cut herself with the zipper when she was putting it on and she died. It's absolutely true, my friend told me, and she was told by her mother who knows a police officer who works on this case. There is supposed to be a trial against the gravediggers. (Czub Mit: 52)

The first segment is dominated by an additivity which is typical of oral tales, while in the second segment an attempt to demonstrate a cause and effect relationship can be observed. The aim of the second part is to authenticate the story by referring to additional proof.

The most common stylistic device used in urban legends, apart from the already discussed formulas, is the epithet, e.g.: wielki szczur ('an enormous rat'), pechowy hydraulik ('an unlucky plumber'), takome psiska ('hungry dogs').

A brief review of epithets reveals a pattern of using this device in the genre. It is used to emphasise the perceived danger of a phenomenon (adjectives such as 'great', 'enormous', 'hungry' are applied to animals that endanger the life or health of the characters), to depict an element that is crucial for the plot (false teeth), or to describe or characterise the protagonist (an unlucky plumber). Those epithets demonstrate that an urban legend is a genre that presents certain fragments of reality in an expressive way, transmitting a sense of danger.

It seems that another common stylistic device used in the descriptions is the euphemism. It is illustrated by how sex, a frequent subject in urban legends, is referred to. The tellers do not use colloquial or vulgar terms for the act itself, instead, they use 'intercourse', 'she did it', 'spends time only with millionaires', 'entertains gentlemen', 'he entered her with an erotic intent', 'she made love to him', 'a coitus occurred between a woman and a dog', or euphemisms for male and female sexual organs ('she grabbed him by the ...', 'it burned everything he had').

The urban legend is dominated by an economical, reporting, even factual style.

\section{Urban legend and folk tale}

In the previous sections of this article, urban legend has been characterised according to its four aspects: structural, pragmatic, cognitive and stylistic aspect. However, it can also be defined by juxtaposing and comparing it to another traditional folklore genre which is relatively close to it - namely the folk tale. 
Texts defined as urban legends have often been compared to traditional folk tales. D. Simonides and J. Hajduk-Nijakowska (1989: 410) notice that both are passed on in the similar way: "Almost one third of the narration is filled with 'authenticating' the story. The narrators quote authorities as the sources of validity of the story, they embellish the events with details, illustrate with specific realities, give information about when and where they heard the story for the first time."

A general glance at the structures of the two genres seems to indicate the similarity emphasised by the two scholars. In both genres the opening and closing formulas are most common. It clearly stems from the subject matter of the two genres and people's approach to these extraordinary events. However, in order to demonstrate the differences between the genres more distinctly, we have to look at which are the particular types of formulas that are used in either genre. The differences sometimes cannot be grasped solely by comparing the types, as they rely on the manner in which a specific formula type is used in a genre. The most informative example is the presence of the testimonial formula in a folk tale and an urban legend. When it comes to the initial formulas, in folk tales the narrator most commonly quotes:

- collective, undefined sources:

Pobliscy mieszkańcy zaczęli więc tłumaczyć to zjawisko, że „krasnoludki piora $w$ Eugu swoje szmaty, ale gdy ktoś z ludzi nadchodzi, wtedy one kryja sie przed nim”.

The local residents explained this phenomenon with "dwarfs washing their rags in the lake, but when anyone comes near them they hide". (Gaj Duchy: 197)

- family members:

Ale czy to [śmieje się], czy to prawda byto panie. To mój rodzony ojciec opowiadat nieros nam na wieczórkach.

But was it [laughs] was it true, mister. My own father told this story more than once during evenings. (E3: 159)

On the other hand, in urban legends, as it was mentioned before, the sender often quotes written sources or acquaintances and friends. The differences between the testimonial formula in folk tales and urban legends indicate different types of interpersonal contacts nowadays and in the past. In the past, knowledge and news were passed on between family members and the ties between generations were stronger, while nowadays, ties within one generation prevail.

Both genres share similar intentions. In both cases the explanation of the unknown seems to be central. But while folk tales are, as Max Lüthi claims, 
"characterised by an extraordinary and thrilling subject - the stories of contacts with the 'other' world" (cited by Mojkowska 2006: 27), urban legends present accounts of unusual 'earthly' events and people. In folk tales the explanations of unknown, disturbing phenomena are sought almost exclusively from the supernatural world (see also Lehr 2013, this volume), while in urban legends the explanations are more often stemming from the human psyche.

The two genres are also differentiated by the manner in which they present the world. In folk tales, next to the real human world, there is a fantastic world which is quite often familiar to people: Byto to prawda i czy się z tego śmiejecie, czy nie, to i tak wszyscy starsi ludzie wiedza, że dawniej utopców można było spotkać przy każdym moście ('It was true, and whether you laugh at it or not, all the elderly people know that you used to meet monsters near every bridge') (Sim Kum: 135). Urban legends present rare and uncommon phenomena that constitute an alien, dangerous and surprising threat for human beings. One can hear about them quite often, but they do not happen frequently.

In both genres, the tellers express a strongly verbalised relation towards the story. In folk tales, however, the narrator tries to convince the audience of the authenticity of the story more frequently and personally declares his or her conviction by using alethic modality. Doubt in the authenticity is rarely expressed. In urban legends, initial epistemic formulas are more common (the opening phrases often constitute authenticity formulas). In a folk tale, authenticity of a story is enforced by the fact that the narrator is sometimes a participant in the event:

Roz to przy szkubaniu pierza styszatach tako historyjo, ale to jest prowda, bo to ta, co rozprawiata, na wtasne oczy widziata, no i ludzie wszyscy $z$ tyj wsi jeszcze nieroz o tym wspominają.

Once, when we were plucking feathers, I heard this story, but it's true, because the one who told us saw this with her own eyes and the people in this village still talk about it from time to time. (Sim Gad: 194)

In both cases "the narrator tells about the intrusion of the supernatural with humour or fear, but does not attempt to interpret the phenomenon, or interprets it in a superficial manner, according to his or her experience and subjective knowledge about the world" (Mojkowska 2006: 27).

To sum up, urban legend is a genre whose structure is determined by distinct aspects - its testimonial or authenticity formulas. It refers to world knowledge, which is common to the teller and the audience alike. The purpose of the genre is to explain the unknown, dangerous situations and to tame them. 


\section{References}

Barber, Mark 2007. Legendy miejskie. [Urban legends.] Warszawa: Wyd. RM.

Brunvand, Jan H. 1981. The vanishing hitchhiker: American urban legends and their meanings. New York City: W. W. Norton \& Company.

Brunvand, Jan H. 1986. The choking doberman and other "new" urban legends. New York City: W. W. Norton \& Company.

Brunvand, Jan H. 2002. Encyclopedia of urban legends. New York City: W. W. Norton \& Company.

Czubala, Dionizjusz 1985. Opowieści z życia. Z badań nad folklorem wspótczesnym. [Tales from life. Research on contemporary folklore.] Katowice: Wyd. Uniwersytetu Śląskiego.

Czubala, Dionizjusz 1993. Wspótczesne legendy miejskie. [Contemporary urban legends.] Katowice: Wyd. Uniwersytetu Śląskiego.

Donovan Pamela 2004. No way of knowing: Crime, urban legends, and the Internet. New York City: Routledge.

Hajduk-Nijakowska, Janina 2005. Żywiot i kultura. Folklorystyczne mechanizmy oswajania traumy. [Elements and culture. Folklore mechanisms of taming trauma.] Opole: Wyd. Uniwersytetu Opolskiego.

Lehr, Urszula 2013. The transcendental side of life. Aquatic demons in Polish folklore. In: L. Laineste \& D. Brzozowska \& W. Chłopicki (eds.) Estonia and Poland: Creativity and tradition in cultural communication, Vol. 2: Perspectives on national and regional identity. Tartu: ELM Scholarly Press, pp. 191-212.

Kalmre, Eda 2013. Rumours and contemporary legends as part of identity creation process. In: L. Laineste \& D. Brzozowska \& W. Chłopicki (eds.) Estonia and Poland: Creativity and tradition in cultural communication, Vol. 2: Perspectives on national and regional identity. Tartu: ELM Scholarly Press, pp. 25-42.

Mojkowska, Aleksandra 2006. Max Lüthi jako bajkoznawca. [Fairy tale expert Max Lüthi.] Wrocław: Polskie Towarzystwo Ludoznawcze: Uniwersytet Wrocławski.

Rydzewska, Joanna 2004. Folklor albo cień oficjalnej cywilizacji. [Folklore or the shadow of official civilization.] Kultura Popularna 3, pp. 111-123.

Simonides, Dorota \& Hajduk-Nijakowska, Janina 1989. Opowiadania ludowe. [Folk stories.] In: D. Simonides (ed.) Folklor Górnego Śląska. [Folklore of the Upper Silesia.] Katowice: Wyd. Śląsk, pp. 393-354.

Thiele-Dohrmann, Klaus 1980. Psychologia plotki. [Psychology of rumours.] Warszawa: Państwowy Instytut Wydawniczy.

Wierzbicka, Anna 1971. Metatekst w tekście. [Metatext in the text.] In: M. R. Mayenowa (ed.). O spojności tekstu. [On text coherence.] Wrocław: Zakład Narodowy im. Ossolinskich, pp. 105-121.

Wojtak, Maria 2004. Gatunki prasowe. [Press genres.] Lublin: Wyd. Uniwersytetu Marii Curie-Skłodowskiej. 


\section{Marta Wójcicka}

\section{Sources}

Czub Leg = Czubala, Dionizijusz 1993. Wspótczesne legendy miejskie. [Contemporary urban legends.] Katowice: Wyd. Uniwersytetu Śląskiego.

Czub Mit = Czubala, Dionizijusz 1996. Nasze mity wspótczesne. [Our contemporary myths.] Katowice: Związek Zakładów Doskonalenia Zawodowego. Zarząd Główny.

E3 = Bartmiński, Jerzy (ed.) 1990. Etnolingwistyka. Problemy języka i kultury. [Etnolinguistics. Problems of language and culture.] Lublin: Wyd. UMCS.

Gaj Duchy = Gaj-Piotrowski, Wilhelm 1993. Duchy $i$ demony $w$ wierzeniach ludowych $z$ okolic Stalowej Woli - Rozwadowa i Tarnobrzega. [Spirits and demons in folk beliefs from around Stalowa Wola - Rozwadow and Tarnobrzeg.] Wrocław: Polskie Towarzystwo Ludoznawcze.

Sim Gad = Simonides, Dorota \& Ligęza, Jozef (eds.) 1973. Gadka za gadką. 300 podań, bajek $i$ anegdot $z$ Górnego Śląska. [Story after story. 300 stories, fairy tales, and anecdotes from Upper Silesia.] Katowice: Instytut Śląski w Opolu Wyd. Śląsk.

Sim Kum = Simonides, Dorota (ed.) 1977. Kumotry diobta. Opowieści ludowe Ślaska Opolskiego. [Devil's companions. Folk stories from the Opole region.] Warszawa: Ludowa Spółdzielnia Wydawnicza. 